\title{
REVISTAMARACANAN
}

Dossiê

\section{Escravizados, pobres e livres e povos originários na história rural de Mato Grosso: as roças e a antítese da propriedade pelos caminhos e quilombos (séculos XVIII e XIX)}

Enslaved, poor and free and native peoples in the rural history of Mato Grosso: the roots and the antithesis of property by the paths and Quilombos (18th and 19th centuries)

Maria Celma Borges* Universidade Federal de Mato Grosso do Sul Três Lagoas, Mato Grosso do Sul, Brasil

Recebido em: 31 ago. 2019.

Aprovado em: 14 nov. 2019.

\footnotetext{
* Professora Adjunta da Universidade Federal de Mato Grosso do Sul, Campus de Três Lagoas. Doutora e Mestre em História e Sociedade pela Universidade Estadual Paulista (UNESP/Assis); graduada em História pela Universidade Estadual de Maringá. (mariacelmaborges2017@gmail.com)

ORCID iD: https://orcid.org/0000-0002-1282-9567

CV Lattes: http://lattes.cnpq.br/4160177534611725
} 


\title{
Resumo
}

Para uma discussão das roças encontradas pelos caminhos e quilombos em Mato Grosso, no período entre a Colônia e o Império brasileiro, é preciso uma breve reflexão das questões do presente, envolvendo os pobres da terra, para então tecer uma incursão na história rural da América portuguesa, a fim de ultrapassar o tripé consagrado pela historiografia tradicional como o explicativo da história do Brasil nos seus três primeiros séculos: a monocultura, o trabalho escravo e o latifúndio. Nesse debate, visamos entender a importância da produção de alimentos para o abastecimento interno e o papel dos roceiros, pobres e livres, escravizados e indígenas em meio a esse universo. Ao partirmos da análise de Correspondências Oficiais e de fontes como Relatos Monçoeiros trabalharemos alguns indícios da presença das roças e dos roceiros, em suas diversas categorias, com ênfase para alguns percursos que ligavam o norte e o sul de Mato Grosso, especialmente no contexto das monções. As roças dos pobres e livres no trajeto das monções dos séculos XVIII e início do XIX, tal como o cultivo dos escravizados nos quilombos do norte e sul de Mato Grosso e as plantações indígenas que abasteciam as incursões sertanistas pelo sul, no XIX, explicitadas especialmente no relato de Derrotas, de Joaquim Francisco Lopes, serão temas abordados por trazerem vestígios de produção de alimentos e lugares em que os roceiros, em sua diversidade, viveram e trabalharam.

Palavras-chave: Roças. Escravizados. Pobres e Livres. Povos Originários. Mato Grosso.

\begin{abstract}
For a discussion of the roads and quilombos (villages of fugitive slaves) found in Mato Grosso, in the period between the Colony and the Brazilian Empire, it is necessary to briefly reflect on the issues of the present, involving the poor of the land, to make a foray into rural history of Portuguese America, in order to overcome the tripod consecrated by the traditional historiography as the explanatory of the history of Brazil in its first three centuries: monoculture, slave labor and patroonship. In this debate, we aim to understand the importance of food production for domestic supply and the role of poor, free, enslaved and indigenous farmers in this universe. Starting from the analysis of Official Correspondence of the Province of Mato Grosso, and from sources such as Relatos Monçoeiros, we will work on some signs of the presence of roças (plantations) and roceiros (country bumpkins), in their various categories, with emphasis for some of the routes connecting the north and south of Mato Grosso, especially in the context of the monsoons. The plantations of the poor and free in the trajectory of the monsoons of the eighteenth and early nineteenth centuries, such as the cultivation of the slaves in the northern and southern quilombos of Mato Grosso and the indigenous plantations that supplied the sertanistas (frontiersmen) incursions by the south in the XIX, in the report of Defeats by Joaquim Francisco Lopes, will be themes approached for bringing traces of food production and places in which the farmers, in their diversity, lived and worked.
\end{abstract}

Keywords: Roças (Plantations). Enslaved. Poor and Free. Native Peoples. Mato Grosso. 


\section{Entre as roças, pobres da terra e suas frestas: da América portuguesa ao tempo presente}

De início poderíamos indagar: qual a relação possível entre as roças e as suas frestas, no período da Colônia e do Império, por entre o norte e o sul de Mato Grosso, e a história rural brasileira no tempo presente? Quais aproximações poderiam ser realizadas entre esses diferentes tempos? Não é preciso muito esforço para o entendimento de que sem a compreensão dos saberes dos roceiros desde a América portuguesa, na escrita de sua história pelo ofício de suas mãos e pelos sonhos cultivados em meio à labuta do trabalho na terra costumeiramente de outrem -, não poderíamos chegar à atualidade e assim entendermos a dinamicidade e a conflitualidade da história rural brasileira, a história das posses e propriedades, e dos diversos agentes sociais que Ihes dão vida, especialmente os pobres da terra, por mais adversa que seja a situação do campesinato ainda no tempo presente. Somamse a isto as lutas camponesas de milhares de sem-terra pelos vários recantos do Brasil, especialmente a partir de fins dos anos 1970, momento em que, retroalimentados por ações ao longo da história, homens e mulheres fizeram com que (re)nascesse a figura do roceiro materializada na categoria de sem-terra, conseguindo congregar interesses e agentes sociais aparentemente díspares em um dos maiores movimentos de luta pela terra de todos os tempos, o Movimento dos Trabalhadores Rurais Sem Terra (MST), somando-se aos vários outros que despontaram pelo território brasileiro ao longo dessas décadas. ${ }^{1}$

Nesta perspectiva, falar do modo de vida e dos conflitos envolvendo os roceiros no norte e sul de Mato Grosso, desde o percurso das monções nos séculos XVIII ao decurso do XIX, ajuda a entender o porquê ainda em nosso tempo é preciso reafirmar, constantemente, que o campesinato existe e é ele quem produz parte significativa dos alimentos que chegam cotidianamente às nossas mesas. Essa premissa de análise se dá ao reverso do discurso que enxerga o "agronegócio" como a "galinha dos ovos de ouro" aos olhos das políticas públicas dos governos estadual e federal, em especial neste cenário das duas primeiras décadas do século XXI. O "agro é pop, o agro é tech, o agro é tudo", campanha publicitária veiculada nos meios de comunicação de massa no Brasil, é um discurso e uma prática que objetivam excluir a agricultura camponesa e os pobres da terra de seu papel de protagonistas da história, apresentando o agronegócio como a síntese dos resultados positivos do campo brasileiro.

1 Conforme Nashieli Rangel Loera: "hoje em dia, existem no Brasil inúmeras organizações de trabalhadores rurais que promovem ocupações de terras e organizam 'acampamentos de lona preta', entre elas o Movimento dos Trabalhadores Rurais Sem-Terra (MST), Movimento dos Agricultores SemTerra (MAST), Associação dos Trabalhadores Sem-Terra de São Paulo (ATST), Movimento do Trabalhador Rural Sem-Terra do Brasil (MTRSB), União dos Trabalhadores Sem-Terra (Uniterra), Organização de Luta no Campo (OLC), Movimento Terra, Trabalho e Liberdade (MTL), Movimento do Trabalhador Rural (MTR), Movimento de Luta pela Terra (MLT), Comissão Pastoral da Terra (CPT) e as federações de trabalhadores rurais estaduais (Fetape, Fetag/RJ, Fetaemg, entre outras) e demais organizações que surgiram ao longo dos últimos anos". LOERA, Nashieli Rangel. Introdução: o mundo das ocupações. In: Tempo de acampamento [online]. São Paulo: Ed. UNESP, 2014, p. 4. 
Ao contrário disso é possível perceber reinvenções e lutas dos pobres da terra, no modo possível de cada dia, a demonstrar a dinamicidade que pulula nesses lugares de produção da vida e que não se limitam à produção de commodities. Bem por isto que é preciso problematizar o discurso do agronegócio como o produtor da vida, pois as evidências históricas têm explicitado o seu reverso. Na contramão dessa história e na busca de um lugar em que a vida possa ser gerida temos as ações de indígenas, sem-terra, assentados, remanescentes de quilombos, atingidos por barragens, entre outras categorias, vivenciando as adversidades para permanecerem em lugares em que o peso do latifúndio e da monocultura (da soja, da cana, do eucalipto, etc.) impõem a esses agentes sociais a necessidade premente de cotidianamente resistirem para manter vivo o sonho da conquista e da permanência em uma terra quiçá um dia liberta.

Como salientado anteriormente, para chegar à história rural em Mato Grosso no contexto da Província vemos a necessidade de uma breve incursão na história das roças pela colônia, especialmente nos caminhos das monções, buscando entender a importância da produção de alimentos para o abastecimento interno e o papel dos pobres e livres, escravizados e indígenas, nesse cenário, especialmente ao produzirem para o autoconsumo e, quando possível, para o comércio de excedentes. Em seguida trabalharemos alguns indícios da presença das roças e desses agentes sociais no sul e norte de Mato Grosso, priorizando, na maior parte do texto, a discussão do sul no contexto da Província. As roças dos pobres e livres no percurso das monções e os quilombos no século XIX, tal como o plantio de alimentos dos povos originários, encontrados no relato de Derrotas, de Joaquim Francisco Lopes, serão abordados por serem lugares de produção de alimentos e espaços em que os roceiros teceram, a contrapelo, a sua história. ${ }^{2}$

\section{Para além do tripé na história do Brasil: a importância das roças e o seu papel no abastecimento interno}

Os recursos naturais retirados da América portuguesa, a exemplo do ouro das Gerais, de Mato Grosso e de Goiás, especialmente no decurso do século XVIII, serviam para beneficiar não somente aos "países metropolitanos", como Portugal, mas aos interesses dos traficantes de escravos e comerciantes brasileiros, senhores de escravos e de terras, e aos administradores que se estabeleciam na Colônia e ainda no Império pelos vários recantos também de outras rotas do Atlântico. Hoje, os estudos da América portuguesa nos mostram que essa elite que se constituía desde a colônia e em outros domínios portugueses, pelas redes que eram estabelecidas, era beneficiada e muito com os recursos das terras coloniais, pois a metrópole, por mais que o quisesse, não dava conta de inibir as fissuras que a classe senhorial

\footnotetext{
2 LOPES, Joaquim Francisco. Derrotas. Campo Grande: Instituto Histórico e Geográfico de Mato Grosso do Sul, 2007.
} 
e de comerciantes impunha em meio à tentativa de controle da administração colonial e imperial, a exemplo do desvio de ouro e do contrabando de escravos. Por outro lado, a história rural do Brasil não se limita à elite e aos seus feitos. Não se reduz ainda à economia mineradora ou mesmo à monocultura da cana de açúcar, do algodão e do café, entre outras economias. É preciso a análise das brechas também abertas pelos pobres da terra. As pequenas roças seriam uma dessas fissuras em meio às grandes concessões de terras, à grande propriedade, e mais tarde face à apropriação privada de vastas extensões em nome da Lei, a exemplo da Lei de Terras de 1850.

Para a análise da história da América portuguesa, afora a necessidade de rediscutir o tripé consagrado na historiografia por Caio Prado Júnior, e reiterado por muitos outros estudiosos, brasileiros e brasilianistas, é preciso inserir ainda a discussão da economia de abastecimento interno, mesmo face às inúmeras intempéries por ela vivenciadas. ${ }^{3}$ Esta reflexão é importante por indicar as possibilidades de fendas que os povos da terra poderiam abrir em meio aos mandos e desmandos dos poderes concentrados na figura dos "homens bons" e dos interesses públicos e privados que se entrecruzavam e se entrelaçavam naquele universo da colônia e do império. Essas frestas que eram forjadas por entre o peso do latifúndio e da monocultura se constituíam de variadas formas, como, por exemplo, na denominada "brecha camponesa" que pode ser entendida, conforme Flávio Gomes e João José Reis, como o plantio de alimentos pelos escravos, em dias livres, como domingos e feriados, em parcelas de terras cedidas pelos senhores dentro dos engenhos e fazendas. Segundo estes autores: "Os escravos cultivavam suas roças e frequentavam feiras e mercados locais nos seus 'dias livres' costumeiros, onde montavam 'quitandas' para vender seus excedentes agrícolas". Observam, todavia, que:

Tais arranjos não resultavam da existência de uma escravidão amena, que fique claro, mas da pressão dos escravos por melhores condições de vida. Por seu turno, muitos senhores achavam que a concessão de roças aos seus escravos podia ajudá-los a conter o potencial de rebeldia destes. ${ }^{4}$

Essas aberturas poderiam dar-se ainda pelo plantio de alimentos às margens dos grandes estabelecimentos em terras consideradas pouco agricultáveis, ou mesmo naquelas que poderiam ser encontradas em seu interior, como faziam os agregados, moradores de favor em terras alheias, ou ainda no cultivo de pequenas posses distantes dos engenhos e fazendas, onde o poder de mando dos senhores de escravos e de terras ainda não conseguira chegar, como faziam os pequenos posseiros, itinerantes, que adentravam mais e mais as terras da Colônia e do Império na tentativa de encontrar um lugar em que pudessem plantar e ver chegar o tempo da colheita. Independentemente da forma como se constituíam, as pequenas

\footnotetext{
${ }^{3}$ PRADO JÚNIOR, Caio. Formação do Brasil Contemporâneo: Colônia. São Paulo: Brasiliense, 1971.

4 GOMES, Flávio dos Santos; REIS, João José. Roceiros, camponeses e garimpeiros quilombolas na escravidão e na pós-emancipação. In: STARLING, Heloisa M. Murgel; RODRIGUES, Henrique Estrada; TELLES, Marcela (orgs.). Utopias Agrárias. Belo Horizonte: Ed. UFMG, 2008, p. 209.
} 
roças existiram, aqui e acolá, como potencialidades e realidades históricas, fazendo com que repensemos o discurso de sua inexistência na história do Brasil. ${ }^{5}$

Também não nos esqueçamos das roças indígenas que brotavam da ocupação das terras e da semeadura pelos diversos povos originários agricultores que as desenhavam em suas veredas e trilhas, a marcar os caminhos no que mais tarde, em muitos casos, se tornariam as estradas oficiais, vias de transporte que ligariam as capitanias e, mais tarde, províncias, contribuindo para a emergência de povoados, arraiais, vilas e cidades. Essas roças, mesmo que os povos originários não quisessem ou mesmo imaginassem, muito alimentaram os projetos colonizadores dos bandeirantes e monçoeiros do século XVI ao XVIII. No século XIX continuariam a abastecer de alimentos os sertanistas que, a mando dos poderes provinciais ou de interesses privados, adentravam as terras no interior do Brasil e eram os responsáveis pelo processo de colonização e pela dizimação de milhares de povos originários e expulsão de outros pobres da terra que eram encontrados por esses caminhos.

Manoela Pedroza revela a importância dos saberes indígenas, em especial para o cultivo das roças de mandioca, entre outras culturas que compunham o abastecimento interno. A mandioca, como sabemos, faz parte da dieta alimentar dos povos originários desde longa data, bem como de todo o restante do povo brasileiro. Conforme a autora, esse tubérculo tem a capacidade de ser plantado durante todo o ano, podendo ser colhido em qualquer época: "tem um longo ciclo vegetativo, que varia de seis meses a três anos. Dentro desse período, pode ser colhida a qualquer tempo ou deixada armazenada na própria terra, sem apodrecer". Reforça ainda que: "Por essa facilidade, a mandioca já havia sido cultivada pelos indígenas anterior ao advento dos portugueses, tornando-se, no decurso da colonização, a base alimentar também dos viajantes, bandeirantes, monçoeiros, entre outros sertanistas". ${ }^{6}$

Segundo Pedroza, a mandioca, e a farinha dela derivada, geralmente misturada com os peixes, carnes, leite, ovos e o que mais pudesse ser encontrado nessas incursões, tornou-se o prato principal de todos os grupos sociais, sendo consumida na colônia até mesmo pelos governadores, como Mem de Sá. Também no século XIX encontramos as referências às roças indígenas e ao plantio da mandioca, em especial pelos apontamentos dos viajantes e sertanistas que adentravam as terras no processo de colonização, mas sem que deixassem de se deparar com a resistência indígena.

Ao trazermos a reflexão para o sul de Mato Grosso, é possível afirmar que, diferentemente do que observara Sergio Buarque de Holanda, ou seja, de que em Camapuã: "Não há notícia de que a farinha de mandioca, de uso tão generalizado no litoral brasileiro, tivesse grande consumo por estas paragens", ${ }^{7}$ Joaquim Francisco Lopes, ao narrar as suas

${ }^{5}$ Quanto a importância das roças e dos roceiros na história do Brasil, desde a Colônia, ver, também: SCHWARTZ, Stuart. Escravos, roceiros e rebeldes. Bauru, SP: EDUSC, 2001.

${ }^{6}$ Ibidem, p. 388.

7 HOLANDA, Sérgio Buarque de. Monções. $3^{\text {a }}$ ed. (ampliada). São Paulo: Brasiliense, 1987, p. 92. Conforme Holanda, no percurso das monções: "A farinha de milho se sobrepunha a de mandioca, considerada a primeira mais nutritiva e mais fácil de ser produzida, haja vista a mandioca requerer no 
Derrotas no cenário do século XIX, nos revela que esse tubérculo, afora outros alimentos, era utilizado como uma forma de os povos originários presentearem aos que chegavam a suas aldeias. Ao narrar o encontro com os Caiuá, ilustra essa questão: "Ajuntou-se lenha e ao calor de uma extensa fogueira nos deitamos, conversando e banqueteando grandes assados de charque, que havia tirado de minhas provisões, e que eles devoraram com grande apetite, restando para nós outros os presentes que eles me faziam de cará, mandioca, milho, etc.". ${ }^{8}$

\section{Relatos Monçoeiros: na busca das roças e dos roceiros por entre o sul e o norte de Mato Grosso...}

A história rural que envolve os pobres da terra, da Colônia ao Império, foi constituída de violência contra esses grupos, mas ainda de resistências e de negociações, como as "brechas", mostrando as fraturas de uma ordem que mesmo desejando sobrepor-se a esses homens e mulheres, por meio do mando e da violência, não conseguia anular a ação humana materializada nas diversas experiências vividas naquele momento histórico. Em outras palavras: no desejo dos roceiros em permanecer na terra, por mais que a condição de itinerância tenha sido a marca do campesinato, fosse pela impossibilidade da permanência na terra devido ao embate com povos indígenas ou mesmo pela concentração da terra nas mãos de poucos, e a consequente expulsão, dentre outras formas de violência.

Se olharmos o percurso das monções, no século XVIII, por exemplo, entre a antiga Araritaguaba, hoje Porto Feliz, em São Paulo - de onde partiam as embarcações monçoeiras e Cuiabá, horizonte daqueles que navegavam principalmente à busca do ouro, no norte de Mato Grosso, na perspectiva de desvelar resquícios que nos indiquem a presença das roças, encontraremos em várias passagens de Relatos Monçoeiros a referência às roças de mandioca, milho, feijão, abóbora, entre outros alimentos cultivados por diversos grupos indígenas, mas também por pobres e livres que, a muito custo - em especial pelo enfrentamento com esses povos -, iam conseguindo manter-se nas terras, ainda que por um tempo curto. ${ }^{9}$

A obra organizada por Taunay, ao narrar o modo de vida e as dificuldades dos monçoeiros no trajeto das monções, traz-nos indícios das pequenas roças que iam se formando pelos caminhos do sul e do norte de Mato Grosso para atender à necessidade de abastecimento dessas rotas fluviais no século XVIII e primeiras décadas do XIX, mas também para a sustentação da vida num lugar marcado pela presença indígena. Vale buscar cada vestígio apontado por esses relatos na tentativa de mapear práticas de cultivo, lugares de ocupação da terra, ainda que provisórios. Buscar ainda os agentes sociais envolvidos e, desse modo, chegar ao conhecimento de parte de suas histórias.

mínimo um ano para a arranca, e o milho produzia de cinco a seis meses, sem contar o fato de poder ser carregado em grãos a distâncias consideráveis". Ibidem, p. 108.

${ }^{8}$ LOPES, Joaquim Francisco. Derrotas. Op. cit., p. 115.

9 TAUNAY, Afonso de E. Relatos Monçoeiros. São Paulo: Itatiaia, 1981. 
Retomamos esses caminhos fluviais vasculhando pegadas que os roceiros possam ter deixado, ao imprimir a sua história no modo de vida possível de cada dia, em um espaço no qual não muito mais tarde se daria a concentração da terra e do poder econômico e político. Nesse percurso nos deparamos com o relato do capitão João Antonio Cabral Camello, ao escrever de Cuiabá para o Padre Diogo Soares, e detalhar a incursão que fez às minas de Cuiabá e Goiás, no ano de 1727. Ao narrar a viagem pelo Rio Grande, Camello nos conta que levaram quatro ou cinco dias entre esse curso e o rio Verde. Nesse trajeto se depararam com dois moradores, como narra o Capitão: "Abaixo da barra do Rio Verde estão dois moradores com suas roças, a primeira da parte esquerda do Rio Grande, com uma capela do Bom Jesus; a segunda da direita, ambas com bastante milho e feijão, que vendem como querem". ${ }^{10}$

É possível encontrar ainda no relato de Camello as impressões quanto aos embates vividos entre os povos indígenas e os roceiros na região do Pantanal, ao observar que: "Postos em marcha começamos a caminhar pelo Pantanal sempre a vista dos morros e atravessamos lagoas e tremedais e, algumas vezes, matos, chegamos, em quatorze dias à primeira roça do Taquary". ${ }^{11}$ Dando continuidade à sua narrativa nos conta que a esta roça encontraram-na deserta, pois: "Fora atacada e destruída pelos Cayapó que haviam trucidado sete ou oito roceiros". ${ }^{12}$

Ao referir-se ao percurso pelo Rio Pardo observou Camello que o rio corre com tanta violência que é preciso conduzir as canoas por meio de varas. Da barra do Pardo ao "Nhanduyassú serão nove ou dez dias; até ele tem estes muitas poucas itaypavas, tem porém neste meio duas roças, em que há muito feijão e bananais". Este sertanista narra ainda que: "Do Nhanduy-assú ao salto do Cajurú serão sete ou oito dias: neles se passam algumas itaypavas; ${ }^{13}$ pouco abaixo do salto há dois moradores com suas roças, e nele se passam as cargas e canoas pela esquerda em pouca distância [...]. Das roças ao Nhanduy-Mirim serão cinco ou seis dias de viagem". Dando prosseguimento à sua narrativa aponta para o encontro de novas roças: "entra este Nhanduy no Rio Pardo pelo mesmo lado, e nasce como o Assu na Vacaria, na barra tem já uma boa roça povoada [...] Desta ao Salto do Caráo serão só dois dias; neles se passam algumas cachoeiras grandes, e se vê uma formosa roça povoada". ${ }^{14}$

Conforme Camello, por todo o Rio Pardo andavam os Cayapó. Observa ainda que "uma légua pouco mais ou menos do nascimento do pequeno rio de Camapuam, encontra-se um sítio, em que estão duas roças povoadas". Quanto a essas roças, o viajante indica a presença

\footnotetext{
${ }^{10}$ NOTÍCIAS Práticas. Das minas do Cuiabá e Goyazes, na Capitania de S. Paulo e Cuiabá, que dá ao Rev. Padre Diogo Soares, o Capitão João Antonio Cabral Camello, sobre a viagem que fez às Minas do Cuiabá no anno de 1727. Revista Trimestral de História e Geographia ou Jornal do Instituto Histórico Geographico Brasileiro, Rio de Janeiro, t. IV, n. 16, jan. 1843.

11 Tremedais significam "pântanos". HOLANDA, Aurélio Buarque de (org.). Novo Dicionário Aurélio. 2a ed.(revista e aumentada). 29a reimp. Rio de Janeiro: Nova Fronteira, 1986, p. 1709.

12 Apud TAUNAY, Afonso de E. Relatos Monçoeiros. Op. cit., p. 33.

13 Itaypava ou Itaipava, quer dizer: "recife de pedra que atravessa um rio de margem a margem, causando o desnivelamento da corrente". HOLANDA, Aurélio Buarque de (org.). Novo Dicionário Aurélio. Op. cit., p. 974.

${ }^{14}$ TAUNAY, Afonso de E. Relatos Monçoeiros. Op. cit., p. 120.
} 
dos roceiros Luis Rodrigues Vilares e Gregório de Matos que viviam nas proximidades de Camapuã e em confronto direto com os Cayapó:

Esses dois pobres roceiros vivem como em um presídio, com as armas sempre em mãos; para irem buscar água, não obstante o terem-na perto, vão sempre com guardas: no roçar, plantar e colher os mantimentos levam sempre todas as armas, e em quanto vigiam uns trabalham outros, mas sempre com as espingardas à mão, e nem com toda esta cautela se livram de que em várias ocasiões Ihes tenha os Caiapó morto a alguns. Colhem contudo bastante milho e feijão, e o vendem muito bem; quando eu fui venderam a dezesseis e dezoito oitavas o milho, o feijão a vinte, e as galinhas, porcos e cabras, como quiseram. ${ }^{15}$

No Rio Quexeim (Coxim) Camello indica "uma roça povoada". No Rio Taquari "Abaixo de itaypavas há duas roças, que se lançaram no ano em que passei aquelas minas, mas como até aqui chegam os Caiapós, não foram de muita dura". Narra ainda que três dias antes da barra do Rio Taquari "está um sítio ou paragem, a que chama de Prensa". ${ }^{16}$ No Rio Cuiabá, semelhante às considerações de Rebello - que discutiremos a seguir - Camello destaca a quantidade de roças em suas margens. Afirma o viajante que ao quarto ou terceiro dia de viagem por este rio se chega:

no Arraial Velho ou Registro, que vem a ser uma roça com muito bom bananal: dia e meio acima desta roça esta outra também povoada, e desta até aos Morrinhos, que serão sete ou oito dias de viagem, a outras duas que dão bastante milho e feijão; porém, dos Morrinhos até a vila, que são seis ou sete dias, quase todo este rio está cercado de roças e fazendas, como também quatro ou cinco acima da mesma vila, e em todas se plantam milho e feijão, em os dois meses do ano Março e Setembro; dão também excelentes mandiocas, de que se faz farinha: há nelas muitas e melhores bananas que as destas minas, e as suas bananas são mais suaves e de melhor gosto: tem já muitas melancias, e quase todo ano; só os melões não produzem em tanta abundância: as batatas são singulares e não menos e são fumos para tabaco e pito. ${ }^{17}$

Ao falar da escassez das roças pelo percurso das monções, a partir das considerações de Camello, observa Taunay que elas poderiam ser encontradas com mais facilidade ao longo do rio Cuiabá, devido à presença do povoamento pela corrida para o ouro das minas:

De Morrinhos à Vila do Bom Jesus, com seis ou sete dias de navegação quase todo o rio estava marginado de roças e fazendas. E este aproveitamento do solo prosseguia a montante de Cuiabá. Plantava-se na região bastante feijão e milho, excelentes mandiocas, das quais se fazia farinha, batatas, fumo e melancias. ${ }^{18}$

Em "Notícia 6a. prática" que também compõe os Relatos Monçoeiros, escrita por Gervásio Leite Rebello, secretário do governador da Capitania de São Paulo e das Minas, Rodrigo César de Menezes, encontramos a narrativa do percurso da cidade de São Paulo para as minas de Cuiabá, iniciada em fevereiro de 1727, um pouco antes da passagem de Camello, conforme Taunay. Rebello, ao referir-se ao trajeto entre o Rio Grande e o Rio Pardo, observa que:

\footnotetext{
15 TAUNAY, Afonso de E. Relatos Monçoeiros. Op. cit., p. 122.

${ }^{16}$ Ibidem, p. 123.

17 NOTÍCIAS Práticas... Op. Cit., p. 128.

18 TAUNAY, Afonso de E. Relatos Monçoeiros. Op. cit., p. 72.
} 
Na quarta-feira, 14 de agosto, deixamos o Rio Grande e entramos pelo Pardo subindo contra a sua grande corrente com excessivo trabalho [...] $\mathrm{Na}$ terçafeira, 20 do dito mês, chegamos às primeiras roças, que de novo fizeram neste rio, e no de Camapoão [...] Na quinta-feira, 22 do dito mês, se seguiu viagem e deixamos à mão esquerda o rio chamado Nhandú-Amy, que faz barra neste, e vem do certão [sic] da Vacaria, passamos também outros ranchos que entram neste mesmo Pardo de uma e outra parte, com não pequeno risco e trabalho, por causa das correntes, pedras e paus que estão caídos e atravessados no rio, e em 29 do dito chegamos às segundas roças do Caijurú, e antes de chegar a elas achamos os seus roceiros em uma cachoeira tirando de baixo da água algumas coisas de duas pobres canoas que se tinham alagado, não havia muitos dias com bastante perda dos donos. ${ }^{19}$

O relato de Rebello, semelhante ao de Camello, desvela a existência de roças pelo percurso das monções, entre os rios Grande (Paraná), Pardo, Camapoã, Nhandú-Amy e o Caijurú, entre outros lugares, ainda que distando léguas umas das outras. Propicia ainda que enxerguemos, mesmo que por meio de parcos indícios, os roceiros em seu modo de vida, a exemplo da retirada de poucos pertences de canoas que haviam naufragado.

No dia 23 de agosto Rebello faz a referência ao local em que se "arrancharam" nas proximidades de um sítio. Conta-nos ainda que no Rio Nhandu-Mirim, no dia 25, fora possível encontrar outra roça, sendo agora a de Bartolomeu Fernandes dos Rios: "Aqui se aposentou a tropa e se comprou mantimento milho a 2 oitavas, o alqueire a $12 .^{\circ}$ de feijão o mesmo e a dúzia de abóboras a oitava". ${ }^{20}$ Era principalmente por meio dessas roças que se abasteciam de víveres para a continuidade da viagem. Milho, feijão, abóboras, como narra o viajante, eram alimentos consumidos por esses caminhos. Camello ainda narra que após a barra do Rio Taquari Mirim, em 9 de outubro, se chegou "a noite a roça de João de Araújo". ${ }^{21}$

Mesmo que no decurso do século XIX, com a expansão da pecuária e, consequentemente das áreas de pastagens, a referência às roças se torne ainda mais escassa e os seus vestígios esparsos, o nosso interesse tem sido mesmo o de buscá-las em meio aos parcos indícios da documentação, para quem sabe descortinarmos lugares, agentes sociais e práticas de produção de alimentos que não podem ser subsumidos pela ação colonizadora, sua economia, e seus empreendimentos públicos e privados, ao demarcarem as terras com o olhar "a perder de vista" - sob os auspícios do Império - como fez Joaquim Francisco Lopes, sertanista que discutiremos a seguir, em especial na referência às roças indígenas.

\section{As roças indígenas nas Derrotas do sul de Mato Grosso}

As roças indígenas aparecem em várias passagens da obra escrita por Joaquim Francisco Lopes e por seu ajudante, João Elliot, intitulada Derrotas, em forma de diário entre os anos de 1829 a 1857. Este relato, publicado em 2010 pelo Instituto Histórico de Mato

\footnotetext{
${ }^{19}$ Apud TAUNAY, Afonso de E. Relatos Monçoeiros. Op. cit., p. 107.

${ }^{20}$ Ibidem, p. 108.

${ }^{21}$ Ibidem, p. 111.
} 
Grosso do Sul e disponível em sua página, narra quatro incursões de Lopes e seu ajudante, acompanhados de pobres e livres, escravizados e povos originários, pelas terras do sul de Mato Grosso, a mando, de início, da administração imperial, mas também de interesses particulares, como o de Barão de Antonina que desejava se apossar de novas terras num tempo anterior a regulamentação da Lei de Terras de 1850.

É interessante mencionar, com base em Márcia Motta, os limites da Lei de Terras de 1850, no sentido da efetivação e do controle da propriedade da terra, em particular das terras devolutas. Isto se dava em Mato Grosso, como em outras Províncias, pela falta de juízes comissários e de agrimensores, por exemplo, para a realização desse trabalho, aparecendo este fato como uma preocupação que pululava nos arquivos da administração pública das Províncias, a exemplo das correspondências oficiais dos presidentes de província endereçadas ao interior. Acresce a isto o desinteresse dos grileiros em regularizar as áreas que diziam ocupar com "efetiva posse", como evidenciam os documentos que temos encontrado na referência ao sul de Mato Grosso, em pesquisas no Arquivo Público de Mato Grosso, em Cuiabá. ${ }^{22}$

Correspondências oficiais disponibilizadas neste acervo demonstram que, passados 11 anos da Lei, em 1861, nenhum dito proprietário de terras havia procurado a Secretaria de Terras Públicas para regularizar a propriedade. ${ }^{23}$ Isso se dava pela falta de funcionários e ainda pelo desinteresse em relação às medições, especialmente por aqueles que poderiam demarcar as terras do modo como desejassem. Exemplo disso pode ser encontrado no fato de que o Presidente da Província de Mato Grosso, Antonio Pedro de Alencastro, em 06 de setembro de 1860, encaminhara ao delegado Diretor Geral de Terras Públicas uma solicitação para que Ihe informasse sobre para qual município, de preferência, deveria nomear-se o juiz da Comissão de Medições, já que não era possível: "por falta de pessoal habilitado, proceder-se já em todos os municípios a medição de terras adquiridas por posses sujeitas à legitimação, ou por sesmarias, ou outras concessões que estejam, por medir e sujeitar à legitimação e revalidação". 24

Ao olharmos para realidades específicas é possível reavaliar a tese do "cativeiro da terra" e problematizar os seus limites, em especial para a efetivação da Lei, principalmente no que se referia à regularização fundiária. ${ }^{25}$ É obvio que a concentração de terras e o grilo eram práticas comuns que se acirraram ainda mais após a Promulgação da Lei de 1850 e de sua regulamentação em 1854, pelo Registro Paroquial, mas o interessante, no caso de Mato Grosso, é perceber o descaso em relação à mesma. Outro exemplo de descaso ou mesmo de enfrentamento em relação aos ditames da Lei de 1850 consta em uma das fontes que

${ }^{22}$ MOTTA, Márcia Maria M. Nas fronteiras do poder: conflito e direito à terra no Brasil do século XIX. Rio de Janeiro: Vício de Leitura; Arquivo Público do Estado do Rio de Janeiro, 1998.

${ }^{23}$ APMT. Registro de Correspondência da Repartição Especial de Terras Públicas (1858-1861). Documento 175, estante 07.

${ }^{24}$ APMT. Registro da Correspondência Oficial entre a Presidência e as Câmaras Municipais, paróquias, bispos, juízes de paz, Diretor Geral dos índios (1859-1862). Documento 181, estante 07.

${ }^{25}$ MARTINS, José de Souza. O cativeiro da Terra. São Paulo: Hucitec, 1979. 
denunciava a retirada de uma cópia da Lei de Terras de 1850 da porta da Igreja em Miranda, ${ }^{26}$ como evidente desejo de ignorá-la. Este ato denuncia o desejo de burlar ou mesmo de se confrontar aos ditames da lei após a sua promulgação.

Retomando a importância das roças pelos caminhos do sul de Mato Grosso, narram as Derrotas que, para a sobrevivência dos sertanistas e dos que os acompanhavam, muitas vezes a alimentação era alcançada pelo acesso às plantações indígenas encontradas pelos caminhos e também por aquelas que eram cultivadas pelos próprios sertanistas, de tempos em tempos, além das caças e pilhagens (entre outros modos de se obter comida). O trecho da obra, a seguir, enuncia a preocupação em cultivar esses alimentos, a fim de que por esses percursos, de idas e vindas, no processo de ocupação e tomada das terras dos povos originários e de outros povos da terra que encontrassem pelo caminho, pudessem reabastecer-se de alimentos: "Fiz roças nas margens do rio Paraná, retirado três quartos de légua, e plantamos". ${ }^{27}$

Além de fornecer o alimento para os que participavam das incursões, as roças indígenas e/ou cultivadas pelos sertanistas e roceiros pobres também contribuíam para o sustento dos animais que acompanhavam essas viagens, como os cavalos e muares. A abóbora e o milho eram cultivados também para esse fim. Como assinalado, em muitas situações eram os próprios dirigentes das incursões sertanistas, junto aos camaradas, escravizados e povos originários que também poderiam ser encontrados nessas viagens, quem plantava esses alimentos, não existindo um lugar fixo para a roça, como sugere o trecho a seguir:

A 18 saímos com sete animais de cargas e quatro de sela; as pessoas que nos acompanharam foram: Sr. Hornelas, dois camaradas, Antônio Cardoso e Manuel Roiz e dois escravos; a 25 continuemos a picada, passando por muitos campestres cerrados e matos; se pôs fogo que arrasou tudo, plantemos milho nas queimadas, pela beira da estrada, em muitos lugares, além de algumas roças dos posseiros... 28

Por este fragmento é possível perceber a composição diversa do grupo que acompanhava Lopes. Para alguns há a explicitação de nome e sobrenome, diferentemente da referência aos escravizados e mesmo aos indígenas, como encontramos em outras fontes. Além das roças de posseiros, como sugere o trecho, muitos alimentos como: "milho, feijão, mandioca, amendoim, cana, algodão e bananeiras" eram cultivados pelos povos originários. ${ }^{29}$ Em várias ocasiões os sertanistas faziam permutas de roupas, facas e ferramentas pelos alimentos das roças indígenas.

Lopes, na Terceira Derrota, ao narrar a chegada à aldeia dos Caiuá, próxima ao rio Ivinhema, nos dá elementos para a compreensão da importância das roças indígenas e a diversidade de alimentos cultivados:

\footnotetext{
${ }^{26}$ APMT. Registro da Correspondência Oficial entre a Presidência e as Câmaras Municipais, paróquias, bispos, juízes de paz, Diretor Geral dos índios (1859-1862). Documento 181, estante 07.

${ }^{27}$ LOPES, Joaquim Francisco. Derrotas. Op. cit., p. 23.

${ }^{28}$ Ibidem, p. 66.

${ }^{29}$ Ibidem, p. 139.
} 
Chegamos enfim ao aldeamento, impropriamente assim chamado, porque as casas acham-se disseminadas e como por bairros. Entramos em um rancho coberto de folhas de caeté, sendo outros cobertos de folhas de jerivá. A aldeia é colocada entre as suas roças ou lavouras, que abundam especialmente em milho, mandioca, abóboras, batatas, amendoins, jucutupé, carás, tingas, fumo, algodão, o que tudo é plantado em ordem; e toda a época é própria para a sementeira, porque vi milho nascer, a emborrachar e a colher-se. ${ }^{30}$

Como demonstra este trecho da obra de Lopes, muitas roças indígenas e de posseiros desenhavam as paisagens rurais do sul de Mato Grosso, inclusive das próprias aldeias, pelos caminhos que ligavam o sul ao norte no século XIX. Nas Derrotas é possível encontrar várias outras passagens em que as roças se tornam o chamariz:

depois de caminharmos cem braças pouco mais ou menos por belos matos saímos em uma roça de meio alqueire de planta de milho, e muito viçoso, tendo no meio um paiol cheio de milho da colheita passada; seguimos adiante e, continuando o caminho, encontramos mais dois paióis de milho e duas roças plantadas; pouco adiante uma tiguera que estava roçando. ${ }^{31}$

No tempo presente, ao observarmos a historiografia brasileira encontramos as marcas das ações dos pobres e livres, dos libertos e dos escravizados, tal como dos povos originários, na constituição dessas roças por quase toda a extensão do Brasil, contribuindo para o conhecimento da história rural e, nela, para a história do abastecimento interno, a mostrar as fissuras abertas, às duras custas, por esses homens e mulheres, pobres da terra, em meio ao latifúndio, a monocultura e ao trabalho escravo.

Como apontado por Gomes e Reis, a partir de trabalhos como os de Ciro Flamarion Cardoso e de Maria Yeda Linhares, ampliamos a abordagem ao discutir a brecha camponesa e o seu papel na Colônia e no Império. ${ }^{32}$ Nesta reflexão não desejamos negar a existência do latifúndio e da concentração da terra e do poder econômico e político no norte e sul de Mato Grosso, centrados nas mãos de poucos, sendo ainda no presente uma realidade dos estados de Mato Grosso e de Mato Grosso do Sul, e do Brasil como um todo, mas sim mostrar as possibilidades de luta e as diferentes formas de resistência dos povos da terra, do passado à contemporaneidade.

Mesmo que essas lutas não tenham invertido a história da concentração da terra e o peso da grande propriedade na vida dos povos da terra, elas não podem ser esquecidas e precisam ser retomadas para que o presente jamais deixe esquecer os arbítrios e os silenciamentos do passado, reproduzidos insistentemente pelos mandos e desmandos dos

30 LOPES, Joaquim Francisco. Derrotas. Op. cit., p. 103. Folhas de caeté, a que se refere Lopes, possivelmente sejam folhas de "mata virgem". HOLANDA, Aurélio Buarque de (org.). Novo Dicionário Aurélio. Op. cit., p. 311. Ainda, segundo Holanda, jerivá (ver jeribazeiros) é uma "Palmeira comum na orla litorânea, de estipe alto e elegante, folha com numerosos segmentos e cujos cocos são secos em mucilagem adocicada, razão porque os apreciam muito as crianças, baba de boi, coquinho, jeribá ou jerivá". Ibidem, p. 987.

31 LOPES, Joaquim Francisco. Derrotas. Op. cit., p. 136. A palavra "tiguera", destacada em itálico, significa: "1. Milharal já colhido e extinto. 2. Roça depois de efetuada a colheita". HOLANDA, Aurélio Buarque de. Novo Dicionário Aurélio. Op. cit., p. 1675.

32 GOMES, Flávio dos Santos; REIS, João José. Roceiros, camponeses e... Op. cit.; CARDOSO, Ciro Flamarion. Agricultura, escravidão e capitalismo. Petrópolis, RJ: Vozes, 1979; LINHARES, Maria Yeda. História do abastecimento: uma problemática em questão (1530-1918). Brasília: Binagri, 1979. 
interesses públicos e privados, como se fosse algo natural. Como nos ensinou Walter Benjamin, os escombros não podem esconder essas histórias sob o risco de apresentarmos somente terra arrasada e negarmos a possibilidade de construção de uma escrita da história a contrapelo. ${ }^{33}$ Uma história de baixo para cima, como sugere Sharpe. ${ }^{34}$ Reconstituir a história dos roceiros, pobres e livres, indígenas e escravizados, desde a América portuguesa, no cultivo de suas roças, é um passo importante para a compreensão da legitimidade das lutas dos povos da terra em pleno século XXI. Bem por isto que carecemos de uma análise do campesinato e de suas ações desde a Colônia. Dizemos isto, pois, comumente, a historiografia das lutas camponesas parece destacar ter como gênese somente as resistências derivadas da negação das arbitrariedades da Lei de Terras de 1850 e das ações que desta Lei adviriam, como, por exemplo, o arraial de Canudos, constituído como um espaço messiânico de desejo de liberdade e de acesso a terra.

Necessitamos de uma inversão dessa análise. E isto só é possível na busca das práticas de resistência e de trabalho dos pobres da terra, ao longo da história rural do Brasil. Nesse exercício, com certeza, encontraremos vestígios do plantio e cultivo das roças, desde a colônia. Isso ainda é possível se olharmos para os quilombos, como fez Gomes ou mesmo Reis e Silva, e enxergarmos as roças, e dentro delas - assim como em toda a sociedade quilombola -, a negociação e conflito vivenciados pelos escravizados nos mais de três séculos e meio de escravidão. São experiências que podem ser encontradas também nos vários outros lugares de produção da vida, a exemplo das roças erigidas pelos pobres e livres nas franjas de uma sociedade que não conseguia - e nem podia, mesmo que quisesse - se limitar ao latifúndio e à monocultura. ${ }^{35}$

Carecemos olhar para além da figura do senhor, do escravo e do imigrante como a síntese da história da América portuguesa e ainda do Império. Talvez esteja mesmo nos pobres e livres, nos escravizados e também nos povos originários, a chave para esta compreensão, expressa quem sabe na compreensão de seu modo de vida e de labuta na terra, como no cultivo das roças. Urge vasculhar os vestígios deixados por esses homens e mulheres na procura do plantio de alimentos, dos roçados e de seu modo de vida por entre as fímbrias de uma ordem que não conseguia ocultar, mesmo que assim o desejasse, as plantações e as mãos, os corpos e os sonhos daqueles/as que por essas terras trabalhavam, que nelas viviam.

Escondidos por entre as paisagens e a exuberância da natureza, tal como pelo peso da economia mineradora e monocultora, como nos faz crer parte significativa da narrativa dos viajantes da Colônia ao Império, faz-se imprescindível o descortinar desses agentes sociais e de suas práticas, para talvez nos sulcos deixados por Linhares e Cardoso e, mais

\footnotetext{
33 BENJAMIN, Walter. Magia e Técnica, Arte e Política. $3^{\text {a }}$ ed. São Paulo: Brasiliense, 1987.

34 SHARPE, Jim. A história vista de baixo. In: BURKE, Peter (org.). A escrita da História: novas perspectivas. São Paulo: Ed. Unesp, 1992.

35 GOMES, Flávio dos Santos. A hidra e os pântanos. Mocambos, quilombos e comunidades de fugitivos no Brasil dos séculos XVII-XIX. São Paulo: Ed. Unesp; Polis, 2005; REIS, João José; SILVA, Eduardo. Negociação e conflito: a resistência negra no Brasil escravista. São Paulo: Companhia das Letras, 1989.
} 
recentemente, por Márcia Motta, entre outros autores, encontrar essas marcas, apreendê-las em vista da práxis humana, da experiência palmilhada pela vida que forçosamente se fazia errante. Se as roças aparecem de forma esparsa, com pouca nitidez em meio à documentação, elas ali estão independentemente das distâncias que as ligavam, e nos mostram a produção de alimentos e da vida em lugares considerados costumeiramente como "vazios", especialmente se trabalharmos na perspectiva dos "sertões" e da figura dos "pioneiros". ${ }^{36}$

\section{Considerações finais: as roças e os quilombos por entre o norte e o sul de Mato Grosso}

São esses sulcos deixados pelos pobres da terra, compreendidos aqui como marcos de uma existência precária e encoberta pelas folhagens e pelo olhar dos viajantes, semelhante à documentação oficial e parte da historiografia, que desejamos encontrar pelos ditos "sertões" entre o sul e norte de Mato Grosso, a fim de desconstruir uma imagem de um "espaço vazio", na medida em que as práticas de colonização ainda não haviam se firmado. Partimos da premissa de que seriam nos "encontros" e "desencontros" entre povos da terra, ${ }^{37}$ escravizados, pobres e livres, indígenas e quilombolas, e também entre bandeirantes e mais tarde monçoeiros que as roças e modos de vida iriam se constituindo, fazendo-se e desfazendo-se.

Os pequenos posseiros, pobres e livres, que se instalavam pelas terras dos povos originários se deparariam com a resistência indígena. Por outro lado, nos estudos dos quilombos os estudiosos do tema apontam para fortes indícios de enlaces de interesses entre indígenas, escravizados e pobres e livres, já que os quilombos ou mocambos se constituiriam dessa diversidade de agentes sociais às margens ou inseridos precariamente na economia dominante. Também no estudo dos quilombos são interessantes as considerações de Gomes e Reis ao enfatizarem a importância das roças na economia quilombola e o seu papel para o abastecimento interno, já que muitos produtos eram apreendidos quando do fim dos quilombos e apresamento ou morte de seus membros. ${ }^{38}$ Uma evidência semelhante às indicadas por ambos os autores pode ser encontrada na Correspondência Oficial, escrita pelo presidente da Província de Mato Grosso, Estevão Ribeiro de Rezende, no ano de 1839, endereçada ao Capitão Joaquim da Silva Prado, em que solicita informações da existência de

\footnotetext{
36 LINHARES, Maria Yeda. História do abastecimento... Op. cit.; CARDOSO, Ciro Flamarion. Agricultura, escravidão e... Op. cit.; MOTTA, Márcia Maria M. Nas fronteiras do poder... Op. cit.

37 Em fontes do acervo do Arquivo Público de Mato Grosso (APMT), outro exemplo de tentativa de domínio dos povos indígenas no sul de Mato Grosso era a concessão de patentes de capitão ou cabo nos aldeamentos, para os indígenas Cayapó, entre outros grupos, a fim de que contribuíssem para o processo de "civilização e catequese" em voga no contexto do Império.

38 GOMES, Flávio dos Santos; REIS, João José. Roceiros, camponeses e... Op. cit., p. 217.
} 
um quilombo nas terras desse fazendeiro, no termo de Cuiabá, ao mesmo tempo em que indica ações para contê-lo. ${ }^{39}$

A seguir apresentamos o documento na íntegra para a percepção de sua riqueza de detalhes e informações do quilombo. Em outras palavras, para a compreensão das evidências históricas das ações dos escravizados em Mato Grosso que, semelhante ao restante da Província e de todo o Império, se organizaram, lutaram, foram reescravizados, resistiram, constituíram roças e sonharam com o cultivo da terra e a colheita num espaço de liberdade, mesmo vivendo em tempos de cativeiro:

\begin{abstract}
Tendo chegado ao conhecimento do governo a notícia de que entre a fazenda denominada Curral dos Viados, pertencente ao Sr. Capitão Joaquim da Silva Prado, e o Rio Manco, termo desta cidade, há um grande quilombo onde existem inumeráveis escravos fugidos em diferentes épocas à muitas pessoas desta Província, os quais possuem ali ranchos, plantações, roças e mais comodidades necessárias para a subsistência, e convindo fazer destroçar o dito Quilombo e capturar os escravos que o compõem, a fim de serem entregues aos seus donos, e de desaparecer também por este modo o perigo a que vivem expostos não só os moradores circunvizinhos, como até os viandantes, o Presidente da Província, certo do muito interesse que o dito Capitão Joaquim da Silva Prado deve ter na extinção do referido Quilombo até mesmo em benefício de sua Fazenda, que segundo consta já por vezes tem sido incomodada pelos mencionados escravos, o incumbe de informar circunstanciadamente ao Governo sobre este assunto obtido não só acerca das paragens em que se supõem existir o quilombo, como do número de escravos que o compõem, suas forças ou recursos e finalmente qual o tempo mais próprio para serem batidos, se desde já, ou no tempo em que se dividem para diversos pontos nos trabalhos das derrubadas para a plantação das roças, e de qualquer forma é de mister que o mesmo Sr. Capitão Joaquim da Silva Prado noticie quem dever ser o trilhador para em vista de suas informações expedirem as ordens convenientes para a prontificação da Força Armada que for necessária para uma tão importante diligência. Palácio do Governo em Cuiabá, 31 de Maio de 1839. Estevão Ribeiro de Rezende. ${ }^{40}$
\end{abstract}

Esta fonte é reveladora da existência das roças e da sua importância para os quilombos no norte de Mato Grosso, assim como da preocupação dos poderes provinciais em conter a esse lugar que se desejava de liberdade. A saída para a derrubada da mata e ao mesmo tempo a plantação de alimentos tornam-se, então, indicadores do quanto às roças eram fundamentais para a sobrevivência do grupo. Por outro lado, era ainda o momento propício para a atuação da força armada, já que, segundo o presidente da Província, era naquele momento de trabalho em grupos que deveria haver a contenção do quilombo por facilitar o apresamento. Segundo a Correspondência havia a informação de que os quilombolas se dividiam "por diversos pontos" para a realização dessa tarefa, o que facilitaria a ação da guarda a fim de que fossem "batidos".

Ao trazermos a reflexão para o sul de Mato Grosso encontramos também evidências históricas das roças nos quilombos, entre outras informações de como se desenhavam esses lugares. Volpato, ao utilizar-se do discurso do mesmo presidente da Província, Estevão Ribeiro

\footnotetext{
39 Uma primeira discussão desta fonte foi realizada em: BORGES, Maria Celma. Roças, quilombolas e os Kayapó: uma história rural de Mato Grosso (séculos XVIII e XIX). Anais do [...]. XXVIII Simpósio Nacional de História. Lugares dos historiadores: velhos e novos desafios. Florianópolis, 2015.

${ }^{40}$ APMT. Registro de Correspondência Oficial com o interior da Província (1838-1839). Documento 056, estante 05 .
} 
de Rezende, de 1 de março de 1840, aponta para existência do quilombo de Piraputanga e a fartura de alimentos devido às roças cultivadas por seus moradores no cenário do século XIX:

Em 1839, foi enviada uma bandeira contra um quilombo situado na barra do rio Piraputanga; os quilombolas resistiram mas foram derrotados. O aldeamento era composto de dezesseis casas de dois ou três lanços e duas ou três de sobrado. Em seu relatório anual, o presidente da província, Estevão Ribeiro Resende, manifestou sua admiração pela qualidade das construções e, mais ainda, pela fartura encontrada nos paióis do aldeamento. O quilombo do Piraputanga tinha suas casas dispostas umas perto das outras, formando uma espécie de praça. Tal disposição, com certeza, tinha o objetivo de facilitar sua defesa. Seus habitantes desenvolviam a agricultura com sucesso, possuíam várias roças. Quando o quilombo foi batido, os componentes da bandeira não foram capazes de carregar os mantimentos armazenados, dada a sua quantidade. Mais uma vez ficava constatada a capacidade organizadora dos quilombos, capazes de produzir, com fartura, os gêneros de que necessitavam. ${ }^{41}$

Concluímos a reflexão com a discussão das roças em dois quilombos em Mato Grosso, no norte e sul, por entendermos o quanto ela contribui para a percepção de práticas e de agentes sociais na produção de alimentos, a dar o contorno para as ações de luta e para a constituição das roças na América portuguesa e no Brasil Império também em outras localidades que não se reduzem ao "centro".

As considerações de Volpato são reveladoras da dinamicidade da organização e da economia camponesa nos quilombos. Ao afirmar que os participantes da bandeira não foram "capazes de carregar os mantimentos armazenados" quando "o quilombo foi batido" a autora revela que, diferentemente da maior parte da Província, a fome parecia não existir nesse lugar que se queria de liberdade. Por ser espaço de liberdade, mesmo com todas as suas limitações, e se defrontar com o "centro" do poder, era então preciso "ser batido", e fora isto o que as forças do governo fizeram. Remanescentes de quilombos e os pobres da terra, de um modo geral, na atualidade, necessitam conhecer essas histórias para que os saberes do passado, as perdas e as conquistas dos escravizados e demais participantes de quilombos e de outros espaços de resistência, se tornem alimento para as suas práticas no presente.

O abastecimento interno e, em especial, as roças camponesas, oriundas das práticas dos roceiros, pobres e livres, quilombolas e indígenas, demonstram a história rural nessa parte do Brasil, desde a Colônia ao Império, e propiciam que a reflexão chegue ao presente. 0 cultivo das roças naquele momento histórico indicava a produção da vida e, ao mesmo tempo, contraditoriamente, o seu cerceamento, a exemplo da violência na destruição das roças nos quilombos e no apresamento de homens, mulheres e crianças, assim como outras ações imersas no processo de colonização frente aos povos originários. Os Cayapó, como narra Giraldin, semelhante a muitos outros povos originários de Mato Grosso, vivenciaram ao longo de sua história a tomada das terras que ocupavam e a usurpação de seus alimentos,

${ }^{41}$ VOLPATO, Luiza Rios Ricci. Quilombos em Mato Grosso: Resistência negra em área de fronteira. In: REIS, João José; GOMES, Flávio dos Santos. Liberdade por um fio: histórias dos quilombos no Brasil. São Paulo: Companhia das Letras, 2011, p. 228. 
encontrados pelas suas roças. ${ }^{42} \mathrm{~A}$ violência deu-se também face aos pobres e livres, pequenos roceiros que, expulsos da terra apossada, tornaram-se caminhantes por outras paragens. Em outros termos, migrantes em tempos outros à busca de um lugar em que a terra pudesse ser germinada e para que pudessem ver chegar o tempo da colheita.

Esses passos no estudo da história rural de Mato Grosso e do Brasil vem se dando em nosso tempo e muito se avançou na reflexão do campo e do campesinato, em especial nas duas últimas décadas do século XXI. Mesmo diante de algumas conquistas, especialmente de trabalhos oriundos de pesquisadores de várias instituições no país, estamos anos luz de uma interpretação da produção do conhecimento que leve em conta a dinamicidade e a beleza dos saberes do campesinato. Estamos anos luz de políticas públicas voltadas aos pobres da terra que não se reduzam às medidas paliativas. Necessitamos de pesquisas que se se debrucem sobre a história rural do Brasil e busquem, quem sabe por meio das roças, os saberes indígenas, negros e do campesinato, em sua dimensão mais ampla, em suas belezas e contradições, em suas conquistas e perdas, em frestas que precisam fundamentalmente escancarar-se para que se tornem portas e janelas abertas para além de suas fissuras.

42 GIRALDIN, Odair. Cayapó e Panará. Luta e sobrevivência de um Povo Jê no Brasil Central. Campinas, SP: Ed. Unicamp, 1997. 


\section{Referências}

BENJAMIN, Walter. Magia e Técnica, Arte e Política. $3^{\text {a }}$ ed. São Paulo: Brasiliense, 1987.

BORGES, Maria Celma. Roças, quilombolas e os Kayapó: uma história rural de Mato Grosso (séculos XVIII e XIX). Anais do [...]. XXVIII Simpósio Nacional de História. Lugares dos historiadores: velhos e novos desafios. Florianópolis, 2015.

CARDOSO, Ciro Flamarion. Agricultura, escravidão e capitalismo. Petrópolis, RJ: Vozes, 1979.

GIRALDIN, Odair. Cayapó e Panará. Luta e sobrevivência de um Povo Jê no Brasil Central. Campinas, SP: Ed. Unicamp, 1997.

GOMES, Flávio dos Santos. A hidra e os pântanos. Mocambos, quilombos e comunidades de fugitivos no Brasil dos séculos XVII-XIX. São Paulo: Ed. Unesp; Polis, 2005.

GOMES, Flávio dos Santos; REIS, João José. Roceiros, camponeses e garimpeiros quilombolas na escravidão e na pós-emancipação. In: STARLING, Heloisa M. Murgel; RODRIGUES, Henrique Estrada; TELLES, Marcela (orgs.). Utopias Agrárias. Belo Horizonte: Ed. UFMG, 2008.

HOLANDA, Aurélio Buarque de (org.). Novo Dicionário Aurélio. $2^{a}$ ed. (revista e aumentada). 29a reimpr. Rio de Janeiro: Nova Fronteira, 1986.

HOLANDA, Sérgio Buarque de. Monções. $3^{\text {a }}$ ed. (ampliada). São Paulo: Brasiliense, 1987.

LINHARES, Maria Yeda. História do abastecimento: uma problemática em questão (15301918). Brasília: Binagri, 1979.

LOERA, Nashieli Rangel. Introdução: o mundo das ocupações, In: Tempo de acampamento [online]. São Paulo: Ed. UNESP, 2014.

LOPES, Joaquim Francisco. Derrotas. Campo Grande: Instituto Histórico e Geográfico de Mato Grosso do Sul, 2007.

MARTINS, José de Souza. O cativeiro da Terra. São Paulo: Hucitec, 1979.

MOTTA, Márcia Maria M. Nas fronteiras do poder: conflito e direito à terra no Brasil do século XIX. Rio de Janeiro: Vício de Leitura; Arquivo Público do Estado do Rio de Janeiro, 1998.

PEDROZA, Manoela. A roça, a farinha e a venda: produção de alimentos, mercado interno e pequenos produtores no Brasil Colonial. In: FRAGOSO, João; GOUVÊA, Maria de Fátima (orgs). O Brasil Colonial. Vol. 3: 1720-1821. Rio de Janeiro: Civilização Brasileira, 2014.

PRADO JÚNIOR, Caio. Formação do Brasil Contemporâneo: Colônia. São Paulo: Brasiliense, 1971.

REIS, João José; SILVA, Eduardo. Negociação e conflito: a resistência negra no Brasil escravista. São Paulo: Companhia das Letras, 1989.

SCHWARTZ, Stuart. Escravos, roceiros e rebeldes. Bauru, SP: EDUSC, 2001.

SHARPE, Jim. A história vista de baixo. In: BURKE, Peter (org.). A escrita da História: novas perspectivas. São Paulo: Ed. Unesp, 1992.

TAUNAY, Afonso de E. Relatos Monçoeiros. São Paulo: Itatiaia, 1981.

VOLPATO, Luiza Rios Ricci. Quilombos em Mato Grosso: Resistência negra em área de fronteira. In: REIS, João José; GOMES, Flávio dos Santos. Liberdade por um fio: histórias dos quilombos no Brasil. São Paulo: Companhia das Letras, 2011. 